\title{
Facebook como Ferramenta de Apoio ao Ensino
}

\author{
Ernane Rosa Martins ${ }^{1}$, Luís Manuel Borges Gouveia ${ }^{2}$ \\ ${ }^{1}$ Instituto Federal de Goiás (IFG) \\ Caixa Postal 72.811-580 - Luziânia - GO - Brasil \\ ${ }^{2}$ Universidade Fernando Pessoa (UFP) \\ Caixa Postal 4249-004 - Porto - Portugal \\ ernane.martinseifg.edu.br, lmbgeufp.edu.pt
}

\begin{abstract}
This article presents the results obtained through an experience with the use of the Facebook Social Network, as support in the pedagogical practices. The research is quantitative approach, with characteristics of an information survey and had as target audience students of the Project Management discipline of the Higher Course in Information Systems (IS). As a result, it was concluded that Facebook, in the opinion of the participants of this study, could be a very effective tool as a support in pedagogical practices.
\end{abstract}

Resumo. Esse artigo apresenta os resultados obtidos através de uma experiência com a utilização da Rede Social Facebook, como apoio nas práticas pedagógicas. A pesquisa é de abordagem quantitativa, com características de um levantamento de informações e teve como público alvo discentes da disciplina de Gerencia de Projetos do curso Superior em Sistemas de Informação (SI). Como resultado, concluiu-se que o Facebook, na opinião dos participantes deste estudo, pode ser uma ferramenta muito eficaz como apoio nas práticas pedagógicas.

\section{Introdução}

Estudos apontam que o Facebook pode ser utilizado como Ambiente Virtual de Aprendizagem (AVA), por reunir diversos tipos de mídias em um único ambiente, possibilitando a aprendizagem colaborativa, a interatividade e a diversas praticas pedagógicas que levam ao aprender a aprender (Ferreira; Correa \& Torres, 2012). Observa-se ainda que os professores das escolas brasileiras, estão resistentes a inserção de tecnologias na sala de aula, por estarem inseridos nas práticas pedagógicas tradicionais, não possibilitando incluir novas tecnologias na escola. Este trabalho tem como objetivo relatar a experiência de uso do Facebook, como auxiliar no ensino e aprendizagem nas aulas de um curso presencial de ensino superior. Este estudo justificase, visto que os profissionais da educação estão cada vez mais discutindo a utilização das redes sociais no contexto educativo. Essa pesquisa procura contribuir com as potencialidades do uso do Facebook em sala de aula e fora dela. Para Ferreira, Correa \& Torres (2012), avanços na aplicabilidade de metodologias inovadoras aliadas à Web 2.0 são extremamente necessárias para que os professores possam melhorar suas práticas pedagógicas diante de alunos conectados com as Tecnologias Digitais da Informação e Comunicação (TDIC). 
O Facebook vem ocupando um espaço importante na educação como plataforma para a comunicação. Mattar (2013, p. 115), aponta que os relacionamentos entre professores e alunos via Facebook gera "um canal de comunicação mais aberto, resultando em ambientes de aprendizagem mais ricos e maior envolvimento dos alunos nos processos de escolarização". Esta rede social permite que os professores utilizem diferentes metodologias para incentivar e motivar os alunos no processo de aprendizagem (Ferreira; Correa \& Torres, 2012). Quando o Facebook é utilizado como recurso ou AVA no ensino, permite ao professor modificar a forma de aprender, de maneira mais interativa e participativa, facilitando a mediação pedagógica e a interação. Esta rede permite incorporar, personalizar, redimensionar, dinamizar e agregar sentido ao aprendizado, com isto se torna mais atrativa, fazendo com que o estudante saia do papel de simples receptor passivo, tornando-se responsável pelo seu próprio aprendizado (Ferreira; Correa \& Torres, 2012). Llorens \& Capdeferro (2011) apontaram como principais potencialidades pedagógicas do Facebook para a aprendizagem colaborativa: favorecer a cultura de comunidade virtual e aprendizagem social, permitir abordagens inovadoras da aprendizagem e permitir a apresentação de conteúdos.

\section{Metodologia}

Esta pesquisa é de abordagem quantitativa, caracterizada pelo levantamento de informações, com a interrogação direta das pessoas, solicitando informações acerca de um problema, por meio de um questionário (Gil, 2008). O estudo, foi resultado de um trabalho proposto pelo professor da disciplina de Gerencia de Projetos do curso Superior em Sistemas de Informação (SI). A experiência contou com a participação de vinte e seis alunos e um mediador, que foi o professor da disciplina, que atuou propondo os temas relacionados à disciplina para discussão on-line por um período de uma semana, em um grupo da disciplina no Facebook, funcionando como um fórum de discussões, parecido com o Moodle, mas com mais familiaridade dos alunos, proporcionando mais interatividade e portabilidade, devido a possibilidade de acesso também pelo smartphones. O mediador, era responsável por conduzir e nortear as discussões. Após os debates sugeridos, um questionário on-line foi enviado para os participantes, para traçar o perfil dos integrantes e recolher informações para compor os resultados da pesquisa. As respostas foram tabuladas com o software Excel, e posteriormente analisadas.

\section{Resultados}

Entre os participantes que responderam o questionário, seis são do sexo feminino e vinte do sexo masculino, sendo que $69,2 \%$ possuem idade entre 18 a 25 anos, $23,1 \%$ entre 25 e 30 anos e 7,7\% possuem mais de 30 anos. As identidades dos participantes foram preservadas. Por meio das respostas fornecidas no questionário, pode-se constatar algumas informações relevantes, conforme a Tabela 1.

Tabela 1. Perguntas e respostas dos alunos.

\begin{tabular}{lll}
\hline Perguntas realizadas & Sim & Não \\
\hline Utiliza o Facebook diariamente? & $100 \%$ & $0 \%$ \\
\hline Os professores fazem parte dos contatos do Facebook? & $76,9 \%$ & $23,1 \%$ \\
\hline Já fez questionamento ao professor pelo Facebook? & $46,1 \%$ & $53,9 \%$ \\
\hline O Facebook pode ser utilizado como apoio ao ensino? & $92,3 \%$ & $7,7 \%$ \\
\hline Ficou satisfeito com a utilização do Facebook na disciplina? & $92,3 \%$ & $7,7 \%$ \\
\hline
\end{tabular}




\begin{tabular}{lll}
\hline Permitiu a troca de informações entre os alunos e entre alunos e professor? & $84,6 \%$ & $15,4 \%$ \\
\hline A utilização do Facebook na disciplina foi importante? & $92,3 \%$ & $7,7 \%$ \\
\hline A utilização do Facebook na disciplina ajudou a tirar dúvidas? & $96,1 \%$ & $3,9 \%$ \\
\hline A utilização do Facebook na disciplina foi eficaz? & $92,3 \%$ & $7,7 \%$ \\
\hline
\end{tabular}

Observa-se na Tabela 1, que o uso do Facebook faz parte do cotidiano dos alunos, todos afirmaram fazer parte da rede, sendo importante pensar em propostas que incluam esta ferramenta nas atividades educacionais. A maioria dos alunos possuem os professores em seus contatos, mas menos da metade fizeram algum tipo de questionamento a algum deles sobre algum tema das disciplinas. A maioria afirmou que o Facebook pode ser utilizado como apoio ao ensino, ficando satisfeitos com a sua utilização, principalmente visto que é uma importante ferramenta de comunicação e compartilhamento de conteúdo. Tendo como principal vantagem a facilidade de troca de mensagens de maneira síncrona, quando estão on-line, ou assíncrona, quando não estão. Esse tipo de comunicação é importante, pois permite ao aluno fazer questionamentos ao professor a qualquer momento, colaborando com o processo de ensino e aprendizagem.

A maioria afirmou que a utilização do Facebook permitiu a troca de informações entre os alunos e entre alunos e professor, em diversos formatos, tais como vídeos, áudios, slides, entre outros, e que a utilização do Facebook foi importante, visto que ajudou os alunos a sanar suas dúvidas. Os alunos comentaram que a praticidade e facilidade que eles têm no acesso ao Facebook, e por ser utilizado entre eles, facilitou o aprendizado. Sentiram-se motivados em participar das discussões por poder disponibilizando links de textos, vídeos e slides. Afirmaram em sua maioria que a rede social facilitou nas discussões, sendo mais fácil interagir on-line, sentindo-se mais à vontade para comunicar. Alguns relataram que quando faltavam as aulas tinham como acessar os conteúdos perdidos, disponíveis on-line, revendo quantas vezes necessário.

\section{Considerações finais}

O trabalho demonstrou que o Facebook possibilitou a comunicação e interação entre os alunos e com o professor, em variados lugares e em qualquer momento. A mediação do professor é fundamental, propondo temas e estimulando a participação. Para os alunos, o Facebook pode ser inserido ao ensino por ser eficaz no apoio as práticas pedagógicas.

\section{Referências}

Ferreira, J. De L.; Correa, B. R. do P. G. and Torres, P. L. (2012). O uso pedagógico da rede social Facebook. Colabor@- A Revista Digital da CVA-RICESU, v. 7, p. 1-16. Acesso em 04 Junho de 2018. Disponível em: http://pead.ucpel.tche.br/revistas/index.php/colabora/ article/view/199/152.

Gil, A. C. (2008). Como elaborar projetos de pesquisa. 4. ed. São Paulo: Atlas.

Llorens, F. and Capdeferro, N. (2011). Posibilidades de la plataforma Facebook para el aprendizaje colaborativo en línea [artículo en línea]. Revista de Universidad y Sociedad del Conocimiento (RUSC). v. 8, n. ${ }^{\circ}$ 2, págs. 31-45. UOC.

Mattar, J. (2013). Web 2.0 e redes sociais na educação. São Paulo: Artesanato educacional. 